\title{
Коллапс социального
}

ЛАТУР Б. (2014). ПЕРЕСБОРКА СОЦИАЛЬНОГО: ВВЕДЕНИЕ В АКТОРНО-СЕТЕВУЮ ТЕОРИЮ / ПЕР. С АНГЛ. И. ПОЛОНСКОЙ ПОД РЕД. С. ГАВРИЛЕНКО М.: НИУ ВШЭ. 384 С. ISBN 978-5-7598-0819-О

\section{Сергей Попов}

Кандидат социологических наук, преподаватель Северо-восточного федерального университета Адрес: ул. Белинского, д. 58, г. Якутск, Российская Федерация 677000

E-mail: s.p.popov@list.ru

Бруно Латур не нуждается в представлении российскому читателю. Его авторитет может ставиться под сомнение во Франции (где его обвиняют в симпатии к правым католическим кругам и недостаточной политической ангажированности), в Великобритании (где ортодоксальные исследователи науки и технологий без обиняков называют его работы «трескучей французской болтовней»), в США (где он крайне редко бывает из-за расхождений во взглядах с американским социологическим истеблишментом), но только не в России. Здесь Латур остается одним из столпов теоретического дискурса: его проклинают и возвеличивают, ему приносят в жертву тонны бумаги и сотни аудиторных часов. Ссылки на него соседствуют со ссылками на классиков марксизма-ленинизма. Он вызывает либо яростное неприятие, либо столь же страстное обожание. В московских социологических кругах Латур больше известен как создатель «социологии вещей» ${ }^{1}$, совместно с Джоном $Л^{2}$ и Мишелем Каллоном ${ }^{3}$, продвигающий в массы акторно-сетевую теорию ${ }^{4}$. В Петербурге - как социолог науки ${ }^{5}$ и теоретик практик 6 . Но независимо от того, скрещивается ли его подход с теорией фреймов 7 , семиотикой ${ }^{8}$, республиканской

(ㄷ) Попов С. П., 2014

() Центр фундаментальной социологии, 2014

1. Латур Б. (2007). Об интеробъективности / Пер. с англ. А. Смирнова под ред. В. Вахштайна // Социологическое обозрение. Т. 6. №2. С. 79-96.

2. Ло Дж. (2006). Объекты и пространства / Пер. с англ. В. Вахштайна // Социологическое обозрение. Т. 5. № 1. С. 30-42.

3. Callon M. (1986). Some elements of sociology of translation domestication of the scallops and fishermen of St Brieux Bay // Power, action and belief: a new sociology of knowledge? / Ed. J. Law. London: Routledge and Kegan Pol, 1986. P. 196-223.

4. Попов С. П. (2014). Рецензия: Law J. After Method: Mess in Social Science Research. London: Routledge, 2004 // Социология власти. № 1. С. 262-266.

5. Хархордин О. (2010). Предисловие научного редактора // Латур Б. Нового Времени не было: эссе по симметричной антропологии. СПб.: Изд-во ЕУСПб. С. 5-56.

6. Волков В. В., Хархордин О. В. (2009). Теория практик. СПб.: Изд-во ЕУСПб.

7. Вахштайн В. C. (2008). «Практика» vs. «фрейм»: альтернативные проекты исследования повседневного мира // Социологического обозрение. Т. 7. № 1. С. 65-95.

8. Напреенко И. В. (2013). Семиотический поворот в STS: теория референта Бруно Латура // Coциология власти. № 1-2. С. 75-98. 
политической теорией ${ }^{9}$ или аналитической топологией ${ }^{10}$, он оказывается релевантным автором для самых удаленных друг от друга дисциплинарных областей.

В чем секрет Латура?

Михаил Соколов в своем недавнем интервью сформулировал ответ на этот вопрос следующим образом: «Бруно Латур - французский то ли социолог, то ли не социолог, который предложил крайне экстравагантную версию социологии. В ней вещи участвуют наравне с людьми. Обычно у нас есть социология человеческих отношений, которые осуществляются между человеческими агентами, а вещи в них участвуют как пассивные объекты или даже вообще не участвуют. А Латур объявил, что мы должны рассматривать на равных вещи и людей, они все вместе участвуют в постоянном переустройстве, пересборке общества. Это, наверное, самая большая постсоветская мода» ${ }^{11}$. Однако такая пренебрежительная отсылка к «моде» резко расходится с тем, что пишет сам Соколов в своем исследовании петербургской социологии, где ему пришлось ввести особый «фактор Латура» как ключевое отличие тех социологов, которые читают западную литературу, от тех, которые читают только друг друга: «Таким образом, мы видим, что на полюсах обнаруженной нами оси, вдоль которой вытянута сеть взаимодействия петербургских социологов, живут представители двух полярно различающихся академических культур: на левом полюсе ассимиляционисты, читающие Латура и компанию, исповедующие ценности политического либерализма, на правом - изоляционисты, пренебрегающие интеллектуальным импортом и верящие в политический и культурный консерватизм» ${ }^{2}$. Если чтение Латура используется как предиктор в аналитическом разложении всего массива «петербургских социологов» на фланги «академических культур», пренебрежительная отсылка к «главной постсоветской моде» уже не выглядит убедительно. В таком контексте перевод и публикация самой провокационной книги Латура «Пересборка социального» издательством Высшей школы экономики кажется знаковым явлением, свидетельством окончательной победы «латурианцев» над «антилатурианцами».

Сам автор называет «Пересборку социального» учебником по акторно-сетевой теории. Довольно смелое утверждение, учитывая, что книга переполнена запретами и указаниями на то, как не надо делать социологию (этому посвящена вся первая часть работы), в ней почти ничего не говорится о том, как ее надо делать: вторая часть содержит в себе только намеки на такие методические предложе-

9. Алапуро Р., Бычкова О., Хархордин О. Инфраструктура свободы: общие вещи и Res Publica. СПб.: Изд-во ЕУСПб, 2012.

10. Вахитайн В. С. (2006). Джон Ло: социология между семиотикой и топологией // Социологическое обозрение. Т. 5. № 1. С. 24-29.

11. Соколов M. M. (2013). Социология не наука. Доступно по адресу: <http://www.vesti.ru/doc. html?id=414992>. (дата доступа: 04.06.2014).

12. Соколов М. М., Сабонова М. А., Губа К. С., Димке Д. В. (2012). Интеллектуальный ландшафт и социальная структура локального академического сообщества (случай петербургской социологии): препринт. М.: НИУ ВШЭ, 2012. 
ния - в действительности же там еще больше критики в адрес консервативных социологов социального.

Социологи социального - это практически все современные социологи, которые верят в то, что социальное существует как особая реальность sui generis. «Основную мысль этой книги можно сформулировать очень просто, - пишет Латур, - социологи, относя прилагательное „социальный“ к тому или иному феномену, обозначают им некоторое устойчивое состояние, комплекс связей, который потом может быть использован для описания какого-то другого феномена. В таком употреблении этого слова нет ничего плохого, пока оно не обозначает то, что уже собрано вместе, без лишних допущений о природе собранного. Однако когда под „социальным“ начинают понимать разновидность материала, пользуясь этим термином как прилагательным того же ряда, что и „деревянное“, „стальное“, „биологическое“, „экономическое“, „ментальное“, „организационное“ или „лингвистическое“, возникают проблемы. Тут значение термина распадается, поскольку теперь он обозначает две совершенно разные вещи: во-первых, сам процесс сборки, а во-вторых, особый тип компонента, который, как предполагается, отличается от других материалов» (с. 11). Тех, кто описывает социальное как «процесс сборки», Латур называет социологами ассоциаций (относя к ним и себя), а тех, кто описывает социальное как «особый компонент» - социологами социального. «Поскольку в обоих случаях происхождение этого слова одно и то же - от латинского корня „socius“, то можно сохранить приверженность изначальным интуициям социальных наук, определив социологию не как „науку о социальном“, а как прослеживание связей» (с. 17).

Но здесь сразу же возникает вопрос. Значит ли это, что «экономическое» и «ментальное» (не говоря уже об «организационном» и «лингвистическом») - все же обозначают особый тип материала? То есть, исследователи языка, организаций, хозяйства и психики имеют право на субстанциализацию своего объекта, тогда как социологи обязаны изучать лишь те способы, которыми «чужие» объекты приходят во взаимодействие или, в терминологии Латура, собираются в «новые коллективы»? Почему? Потому, отвечает Латур, что возможности изучения социального как особого материала исчерпаны и нужно «добавить капельку релятивизма» в социологическое мышление, чтобы увидеть социальное как «тип связи», а не «тип связываемого». Иными словами: «Социальное в разбавленном виде есть всюду, а в чистом - нигде» (с. 12).

Это довольно бессодержательный ответ. На презентации книги в Библиотеке им. Достоевского (где собралось более 50 желающих послушать о латурианском подходе к социологии) неоднократно отмечалось, что Латур местами просто цитирует Г. Зиммеля без всякой ссылки на него: «...прилагательное „социальное“ обозначает не вещь среди других вещей, вроде черной овцы, затесавшейся среди белых, а тип связи между вещами, которые сами по себе не являются социальными» (с. 17). А какими же тогда они являются? У Г. Зиммеля - который вполне мог бы быть автором процитированной латуровской фразы - есть ответ на этот 
вопрос. Для него социальное - есть форма, а психическое или историческое содержания, которые этой формой соединяются: «Все то, что наличествует в индивидах (непосредственных конкретных носителях исторической действительности) в виде влечений, интересов, целей, стремлений, психических состояний и движений, то, из чего формируется воздействие на других людей или что способствует восприятию этих воздействий, я обозначаю как содержание, т.е. материю обобществления» ${ }^{13}$. Заменяя зиммелевскую дихотомию формы и содержания оппозицией «материала» и «типа связи», Латур сохраняет релятивистский пафос, но теряет возможность осмысленного ответа на простой вопрос: почему психическое может быть «вещью среди других вещей», а социальное - нет.

Что теперь занимает у Латура место, которое у Зиммеля занимала «форма обобществления»? Понятие фигурации - недвусмысленно (и без ссылки) заимствованное Латуром у Н. Элиаса ${ }^{14}$. «Фигурация - пишет Латур, - один из технических терминов, нужный мне для того, чтобы вывести из строя коленный рефлекс „социального объяснения“, потому что очень важно усвоить, что существуют далеко не только антропоморфные формы... Огромная трудность в АСТ не оказаться запуганным типом фигурации: идео-, или техно- или биоморфизмы - все суть морфизмы в той же мере, как воплощение какого-то актанта в конкретном индивиде» (с. 78-79). Получается, акторно-сетевая теория - это просто разновидность «формальной социологии», традиции, которая связывает Зиммеля, Элиаса и Латура? Сам Латур определяет ее интеллектуальные истоки иначе: «Было бы довольно точным описание АСТ как „полугарфинкель, полугреймас“: она просто соединила в себе два наиболее интересных интеллектуальных направления по обе стороны Атлантики...» (с. 79).

Два вопроса, которые не отпускают Латура на протяжении всей книги, вплоть до второй ее части кажутся синонимичными: «Что такое общество? Что значит „социальное“?» (с. 13). В действительности, у этих слов - по признанию самого Латура - совершенно разное происхождение и разная имажинерия. Корень социального - «seq-, sequi-» - т.е. «следовать». «Латинское слово „socius“, - продолжает Латур, - означает „спутник“, „товарищ“. Историческая генеалогия слова „социальное“ изначально восходит к „следованию за кем-то“, затем идет „членство“ и „объединение“ и, наконец, „иметь что-то общее“. Начав с определения, распространяющегося на все виды связей, теперь мы в обыденном словоупотреблении ограничиваем это слово тем, что осталось после того, как политика, биология, экономика, право, менеджмент, технология и т.п. забрали свои доли связей» (с. 17-18). Это, говорит Латур, этимологическая траектория постоянно сужающегося значения Социального, из-за которой мы теперь не можем распространить его на «... кораллы, бабуинов, деревья, пчел, муравьев и китов».

13. Зиммель Г. (1996). Избранное. Т. 2: Созерцание жизни. М.: Юрист, 1996. С. 485. Более подробно об этом см.: Филиппов А. Ф. (1996). Обоснование теоретической социологии: введение в концепцию Г. Зиммеля // Зиммель Г. Избранное. Т. 2: Созерцание жизни. М.: Юрист, 1996. С. 569-599.

14. Элиас Н. (2001). Общество индивидов. М.: Праксис. 
Траектория понятия «общество» иная: «Общество - это изобретение XIX столетия, странная переходная фигура, в которой смешаны Левиафан XVIIII века и коллектив XXI... Со времен мифа об общественном договоре политическое тело, как заметил Джон Дьюи в своем ответе Липпману, всегда было проблемой, призраком, вечно витающим на грани полного исчезновения. Никогда не предполагалось, что фантом превратится в субстанцию, сущее, сферу sui generis... Пока мы ищем за коллективом тень общества, а за обществом тень Левиафана, никакая наука о социальном не может продвинуться вперед... Говоря еще более резко, или общество - или социология» (с. 227-229).

Уже одного этого тезиса достаточно, чтобы отнести Латура к тому классу современных авторов, которых В. Вахштайн называет «посткритическими социологами» ${ }^{15}$. Но с одной очень существенной оговоркой. Если, скажем, Джон Урри стремится избавить социологию от идеи общества ${ }^{16}$ с тем, чтобы дать (вполне консервативно понимаемому) социальному предстать перед исследователем в виде множественных мобильностей, то Бруно Латур избавляется и от «общества», и от «социального» ${ }^{17}$. На место общества должен прийти «коллектив», на место социального - «ассоциации», на место социологии - медленное прослеживание того, как несоциальные по природе своей сущности ассоциируются в коллектив. Именно медленное. Латур называет этот тип этнографии «slowciology» (игра слов, которая в русском переводе книги не очень точно передана странным новообразованием «ползология»).

Социальное и Общество оказались у Латура предельно различными, но равно враждебными сущностями. Им на смену должно прийти нечто радикально иное - то, что он сам не в состоянии определить с необходимой степенью ясности (из-за этого его «учебник» изобилует метафорами и аллюзиями, но не содержит ни единого определения). Самое же интересное состоит в том, что главные чита-

15. «Отношение социологии к своему объекту - именуемому обществом или социальным - можно (очень условно) разделить на три фазы. В начальной фазе объект мыслится как существующий независимо от описывающей его дисциплины. Социолог должен установить объективные законы социального (в жесткой позитивистской версии нашей науки) или истолковывающим образом понять его (в более мягкой неокантианской версии). Это докритическая социология, еще не включившая полностью саму себя в свой собственный объект изучения. Вторая фаза: расширение и размывание границ объекта. Теперь социолог мыслит общество как источник и основание знания. Социология становится способом рефлексии общества о самом себе. Таким образом, основное предназначение социального ученого - критика общества (в самом широком смысле, по аналогии с кантовской „Критикой чистого разума“). Эта критика может приобретать вид атаки на существующий „общественный строй“ или оставаться в границах умеренного „социологического просвещения“; обе версии такой критики объединяет представление о социологии как о продолжении своего собственного объекта, о неизбежно социальном характере самой социологической науки. Наконец, третья фаза - свидетелями которой мы сегодня становимся - начинается с сомнения не только в привилегированном положении общества и социального как сущностей особого рода, но и в самом их существовании» (Вахштайн В. С. (2012). Пять книг о посткритической социологии // Социология власти. № 6-7. С. 275-276).

16. Урри Дж. (2012). Социология за пределами обществ: виды мобильности для ХХІ столетия. М.: НИУ ВШЭ.

17. Latour B. (1999). Gabriel Tarde and the end of the social // The social in question: new bearings in history and the social sciences / Ed. P. Joyce. London: Routledge. P. 117-132. 
тели Латура в России - вовсе не латурианцы. Никто из них не готов поступиться социальным ради сомнительного нового товара - ассоциаций, типа связи, плазмы или сети. Почему же тогда существует обнаруженный Соколовым «фактор Латура»? Почему «читать Латура» и «читать современную западную литературу» стали в России словами-синонимами (хотя для самого Латура они скорее антонимы)? Обоснованный ответ на этот вопрос должны дать социологи науки. Мы же позволим себе высказать гипотезу. Российские ученые восприняли Латура не как ресурс, а как продуктивный вызов для своих собственных исследований. С его аллюзиями и метафорами работают те, кто изучает материальную оснастку социальной жизни - трубы ЖКХ ${ }^{18}$, городское пространство ${ }^{19}$ и структуру детской игры ${ }^{20}$. Иными словами, те самые социологи социального, призывом к низвержению которых и является эта книга.

\section{The Collapse of the Social}

\section{Sergey Popov}

Lecturer, North-Eastern Federal University in Yakutsk

Address: 58 Belinskiy str., Yakutsk, Russian Federation 677980

E-mail: s.p.popov@list.ru

Review: Peresborka social'nogo: vvedenie v aktorno-setevuju teoriju [Reassembling the Social: An Introduction to Actor-Network Theory] by Bruno Latour (in Russian) (Moscow: HSE, 2014).

18. Алапуро P., Бъчкова О., Хархордин О. (2012). Инфраструктура свободы: общие вещи и Res Publica. СПб.: Издательство ЕУСПб.

19. Вахштайн В. С. (2014). Пересборка города: между языком и пространством // Социология власти. № 2. С. 9-38.

2о. Вахштайн В. С. (2013). К микросоциологии игрушек: сценарий, афорданс, транспозиция // Логос. № 2. С. 3-37. 